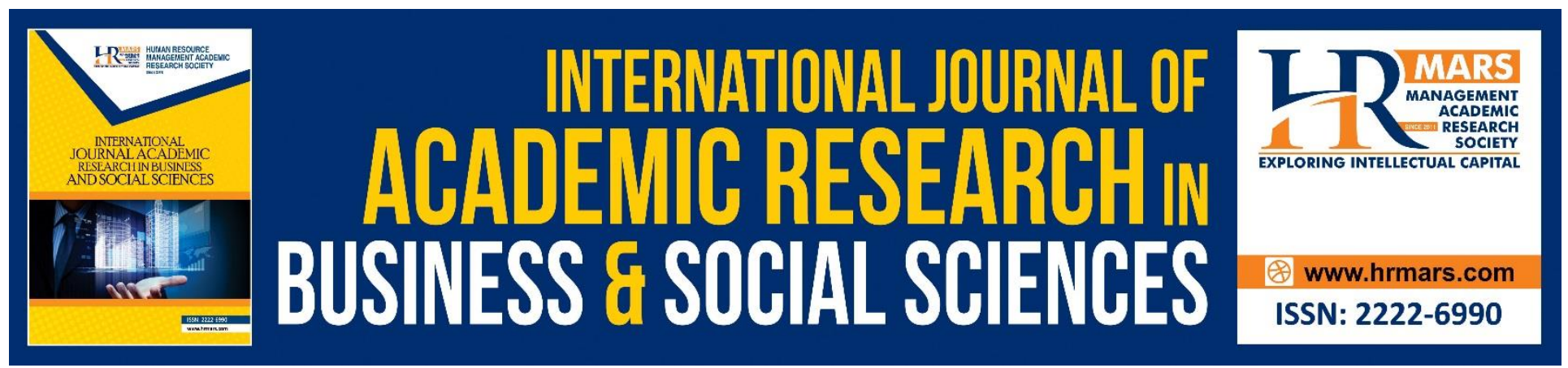

\title{
DIKW Application on Knowledge Based Framework with Situational Awareness
}

\author{
Wan Su Emi Yusnita Wan Yusof, Omar Zakaria, Zuraini Zainol, Ananthan.S
}

To Link this Article: http://dx.doi.org/10.6007/IJARBSS/v8-i6/4305

DOI: $\quad 10.6007 /$ IJARBSS/v8-i6/4305

Received: 21 May 2018, Revised: 20 June 2018, Accepted: 30 June 2018

Published Online: 08 July 2018

In-Text Citation: (Yusof, Zakaria, Zainol, \& Ananthan, 2018)

To Cite this Article: Yusof, W. S. E. Y. W., Zakaria, O., Zainol, Z., \& Ananthan, S. (2018). DIKW Application on Knowledge Based Framework with Situational Awareness. International Journal of Academic Research in Business and Social Sciences, 8(6), 1110-1120.

Copyright: (c) 2018 The Author(s)

Published by Human Resource Management Academic Research Society (www.hrmars.com)

This article is published under the Creative Commons Attribution (CC BY 4.0) license. Anyone may reproduce, distribute, translate and create derivative works of this article (for both commercial and non-commercial purposes), subject to full attribution to the original publication and authors. The full terms of this license may be seen

at: http://creativecommons.org/licences/by/4.0/legalcode

Vol. 8, No. 6, June 2018, Pg. 1110 - 1120

http://hrmars.com/index.php/pages/detail/IJARBSS

JOURNAL HOMEPAGE

Full Terms \& Conditions of access and use can be found at http://hrmars.com/index.php/pages/detail/publication-ethics 


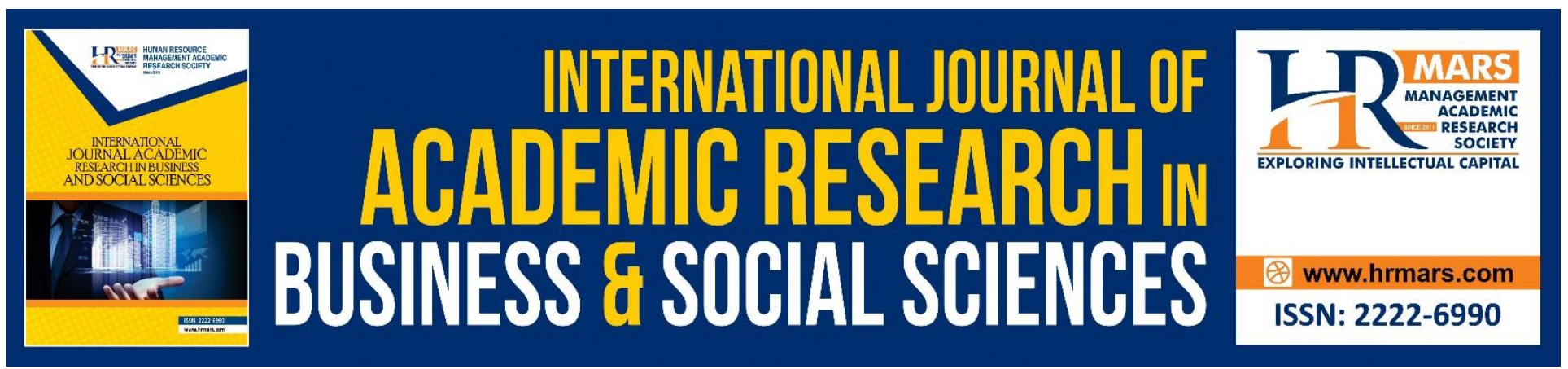

\title{
DIKW Application on Knowledge Based Framework with Situational Awareness
}

\author{
Wan Su Emi Yusnita Wan Yusof ${ }^{*}$, Omar Zakaria² ${ }^{2}$ Zuraini Zainol ${ }^{3}$, \\ Ananthan. $S^{4}$ \\ ${ }^{123}$ Department of Computer Science, Faculty of Science and Defence Technology, National Defence \\ University of Malaysia, \\ Sungai Besi Camp 57000 Kuala Lumpur, Malaysia. \\ ${ }^{4}$ Department of Human Resource Management, Faculty of Defence and Management Studies, \\ National Defence University of Malaysia, \\ Sungai Besi Camp 57000 Kuala Lumpur, Malaysia.
}

\begin{abstract}
Currently, there is no formal method of collecting valuable tacit knowledge especially on MILOBS which they gained through experiences and formal training skills. The problem arises when the MILOBS have come to the end of their service in which they will bring along the knowledge. Furthermore, these issues become crucial when the knowledge is not fully transferred to the new person in charge. Therefore, there is a need to extract the tacit knowledge through a systematic approach. The approach in developing a new framework as a guideline combines elements of Data Information Knowledge and Wisdom (DIKW) hierarchy. In short, DIKW hierarchy can help us to understand more about MILOBS' tacit knowledge. The objective of this paper is to interpret knowledge and wisdom in the DIKW hierarchy into the knowledge based framework with situational awareness analysis. The findings of this study are to propose a new framework and to improve the traditional model of knowledge creation on Nonaka's model by adding the element of situational awareness and wisdom.
\end{abstract}

Keywords: Knowledge Based, Endsley's Model, Framework, Nonaka's Model, Situational Awareness, Peacekeeping

\section{Introduction}

Knowledge is information that has been learned, in other words, knowledge is information in action (Zakaria, 2013). Knowledge based (KB) is a process that help organisation to deploy important knowledge which is part of the individual memory, usually in the form of unstructured format. In order for an individual to be successful, knowledge must exist in a format that can be exchanged among person and it also must be able to grow as well (Wan Yusof, Zakaria, \& Zainol, 2016). According to Gamble and Blackwell (2001), knowledge can be described as processed information on sets of experiences, values, contextual information, expert insight, and grounded intuition which can lead to 
INTERNATIONAL JOURNAL OF ACADEMIC RESEARCH IN BUSINESS AND SOCIAL SCIENCES

Vol. 8, No. 6, June 2018, E-ISSN: 2222-6990 @ 2018 HRMARS

derive new information and practices. In many knowledge theories (Nonaka, 1994, 2008), knowledge can be categorized into explicit and tacit knowledge. Knowledge that has been documented is called as explicit whereas knowledge which is based on undocumented lesson learnt, experiences and training skills is known as tacit knowledge (Nohuddin \& Zainol, 2014; Zainol et al., 2017b; Zainol et al., 2017a). Similarly, in Military domain, knowledge also can be categorized into (i) explicit and (ii) tacit knowledge. In the military context, the explicit military knowledge is often discussed as knowledge that can easily articulated, codified, accessed and stored into various media forms such as (i) Doctrine, (ii) Tactics, Techniques and Procedures (TTPs), etc. (Nohuddin et al., 2010).

This study applies a combination of two (2) models namely the Nonaka's and the Endley's model. This study relates to how the relationship between knowledge and wisdom in DIKW knowledge hierarchy is adopted through both models. Therefore, the combined result of both models has become a guide to collect the experiences of Military Observers (MILOBS) in the face of critical situations faced in the field during peacekeeping operations and the actions they have taken to deal with such situations

\section{Military Observers}

Most militaries of the world are routinely called to undertake operations under the 'Military Operations Other Than War (MOOTW)' concept. The main objectives of these operations are focused on deterring war, resolving conflict, promoting peace, and supporting civil authorities in response to domestic crisis. MOOTW may involve elements of both combat and noncombat forces to undertake operations in peacetime, conflict and even during war time situations.

One such major operation under MOOTW is peacekeeping operations. Since the formation of the United Nations in 1945, the first peacekeeping involving MILOBS was in 1948 to monitor the ceasefire in Palestine. Later on, the first deployment of military troops to keep the peace was undertaken during the Suez Canal crisis in Egypt in 1956 (Koops, MacQueen, Tardy \& Williams, 2015).

The United Nations undertakes peace keeping operations all over the world. The purpose of these missions range from peacebuilding, to peacekeeping and peace enforcement. Currently, there are over 16 peacekeeping missions throughout the world in locations where there border issues, intrastate conflicts and other humanitarian crises (United Nations, 2017). Besides the placement of United Nations civilian staff and police personnel, peace keeping missions require large numbers of military officers and troops from different nations to be deployed to undertake various functions in some of the most hostile environments.

These military officers and troops are generally deployed under two categories; 1 ) as peacekeeping troops deployed with weapons and other armament, and 2) MILOBS (usually officers) without weapons. By and large, the majority of military officers function as multinational MILOBS. They are required to be unarmed, wear national military uniforms, UN shoulder patch and blue berets. These officers are usually of the rank between Captain to Colonel. They receive extensive training at international peacekeeping training centers prior to their deployment to serve under the UN banner. At the mission area, MILOBS as peacekeepers operate in small teams. Their main role is to deploy in conflict zones to patrol and report on the observance of peace agreements signed by the two or more warring factions. Some of the main tasks assigned to MILOBS are as follows (Government of Canada, 2017):

i. to monitor and report on the military situation in their area of responsibility; and

ii. to investigate and document alleged violations of ceasefires or other military arrangements.

iii. disarming and demobilizing belligerent forces; 
INTERNATIONAL JOURNAL OF ACADEMIC RESEARCH IN BUSINESS AND SOCIAL SCIENCES

Vol. 8, No. 6, June 2018, E-ISSN: 2222-6990 @ 2018 HRMARS

iv. supervising the collection and destruction of weapons; and

v. assisting election teams.

vi. other task which includes negotiation, escorting, search operations, show of force and cordon.

Besides these tasks, MILOBS are also responsible for building and maintaining relationships with people living in the mission area, especially community leaders and police. In this role, they provide liaison between the mission and elements of the host government. MILOBS also advise aid agencies on security in their area of operations and help to defuse potential conflicts between hostile factions.

\section{DIKW Hierarchy}

Data (or more accurately a datum) is a collection of facts, measurement and statistics, value, and by itself this has no meaning (Cooper, 2014). Data is symbols that represent properties of objects, events and their environments. Data itself is of no value until it is transformed into a relevant form (Fricke, 2008)Data are defined as symbols that represent properties of objects, events and their environment (Rowley, 2007)This indicates that the data is something that has not been processed or raw facts.

When data is placed in a context it acquires meaning which is structured and organised as the result of cognitive processing and validation becomes information (Cooper, 2014). Information is inferred from data (Rowley, 2007). Information can also be inferred from data, it does not have to be immediately available. Information is relevant data, together with, on occasions, the results of inferences from that relevant data (Frické, 2009). In conclusion, information is something that has been processed and has a meaning as a result from processing of the raw data.

Knowledge based $(\mathrm{KB})$ is a process that help organisation to manipulate important knowledge which is part of the individual memory, usually in the form of unstructured format. In order for an individual to be successful, knowledge must exist in a format that can be exchanged among person and it also must be able to grow as well. Knowledge is often referred to "know about" meaning explicit knowledge. There are how individuals familiar with the existing knowledge in their mind. Other than that, the individual should have a desire to "know how" meaning implicit knowledge. There is how individuals turn an existing knowledge into reality. Conclusion for relationship "know about" and "know how" it has triggered "knowledge" of the individual self as shown in figure 1. 


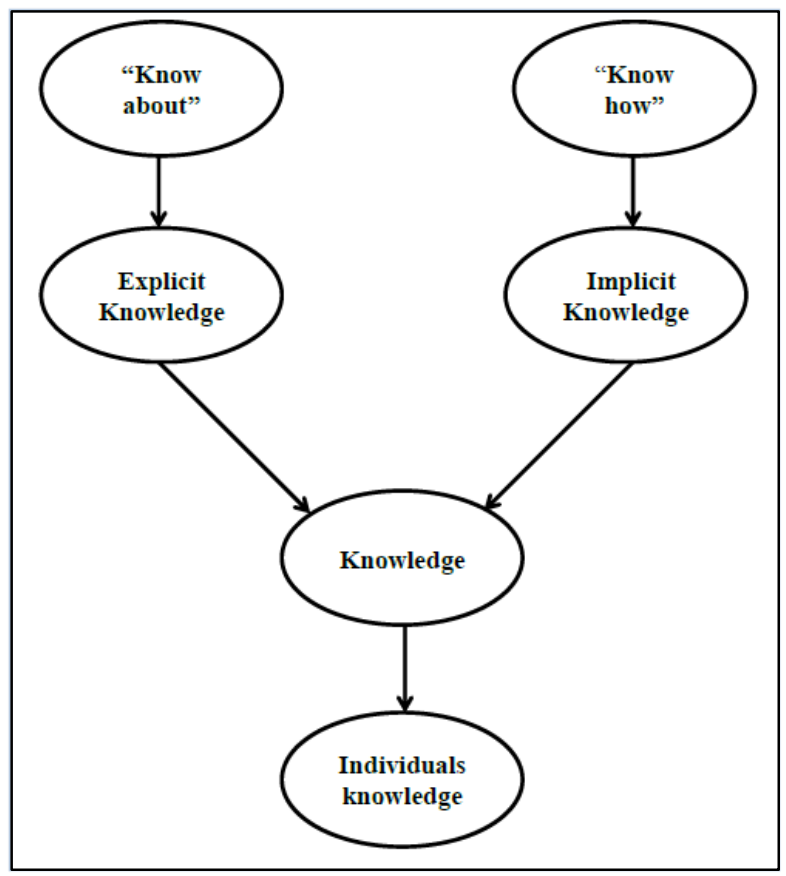

Figure 1: Relationship between "know about" and "know how"

Wisdom is the process by which we discern right from wrong and good from bad (Cooper, 2014). Wisdom is often placed at the highest level of abstraction in the knowledge pyramid which is one individual has ability to make the decision beyond the possibility. Rowley \& Slack (2009) stated that wisdom is embedded in or exhibited through action; involves the sophisticated and sensitive use of knowledge; is often exhibited through decision making; and involves the exercise of judgment in complex real-life situations.

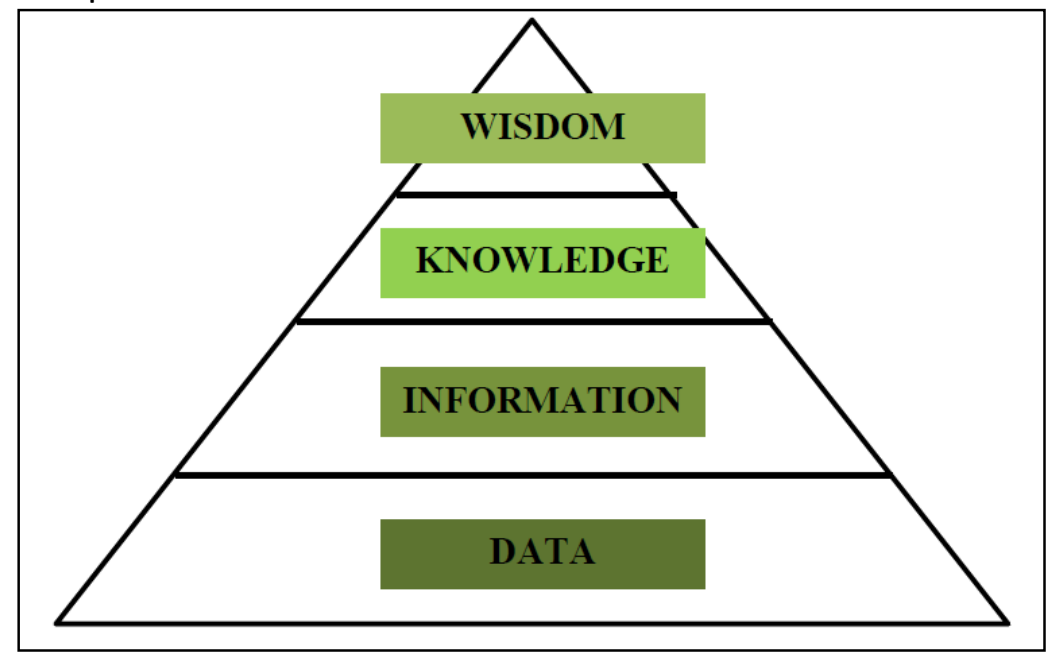

Figure 2: The traditional knowledge pyramid adopted from Rowley \& Slack (2009)

Figure 2 presents the model of traditional knowledge pyramid. Data, for instance, is considered to be unprocessed raw facts. Meanwhile information is considered to be data that has been processed in some meaningful ways. Next, knowledge is considered to be information that has been processed in some meaningful ways and wisdom is considered to be knowledge that has been processed in some meaningful way (Anand \& Singh, 2011). 
INTERNATIONAL JOURNAL OF ACADEMIC RESEARCH IN BUSINESS AND SOCIAL SCIENCES Vol. 8, No. 6, June 2018, E-ISSN: 2222-6990 @ 2018 HRMARS

\section{The Application of Knowledge Hierarchy on Nonaka's Model}

An organisation creates knowledge through the interactions between explicit knowledge and tacit knowledge (Nonaka, Toyama, \& Konno, 2000). According to Nonaka, the interaction between these two (2) types of knowledge is known as knowledge conversion. In this conversion process, the explicit and tacit knowledge expand in both quantity and quality. Figure 3 shows four (4) modes of knowledge conversion. The first mode is a socialisation from tacit knowledge to tacit knowledge. Second mode is externalisation from tacit knowledge to explicit knowledge. The third mode is a combination from explicit knowledge to explicit knowledge and finally, the last mode is internalisation from explicit knowledge to tacit knowledge.

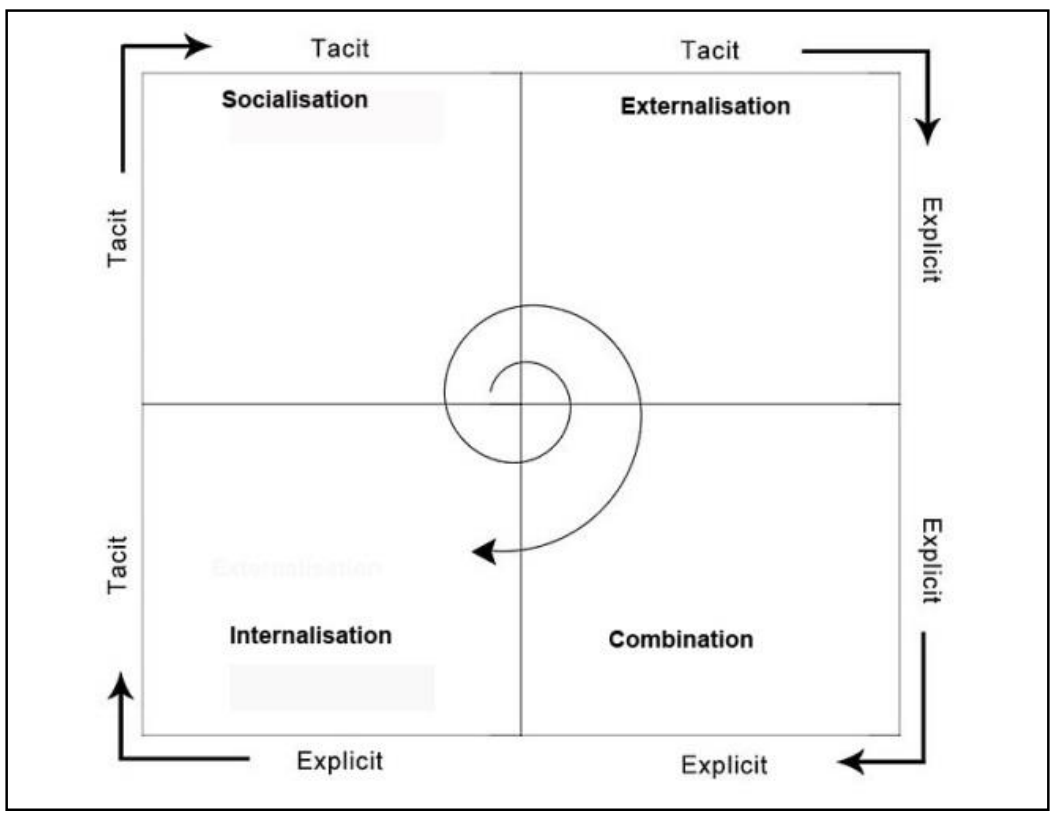

Figure 3: Nonaka's SECI Model adopted from (Nonaka, 1995)

The processes in Nonaka's model and interpretation using an example from this research are illustrated in Figure 4. Socialisation is interpreted as a transform tacit knowledge in the Malaysian MILOBS mind to researcher's tacit knowledge. For externalisation interpretation, it is a recorded data which has been written. Meanwhile for the combination, the data is converted into meaningful information. Then for internalisation, user requirement will produce for next candidates of military observer for their additional reference. 
INTERNATIONAL JOURNAL OF ACADEMIC RESEARCH IN BUSINESS AND SOCIAL SCIENCES Vol. 8, No. 6, June 2018, E-ISSN: 2222-6990 @ 2018 HRMARS

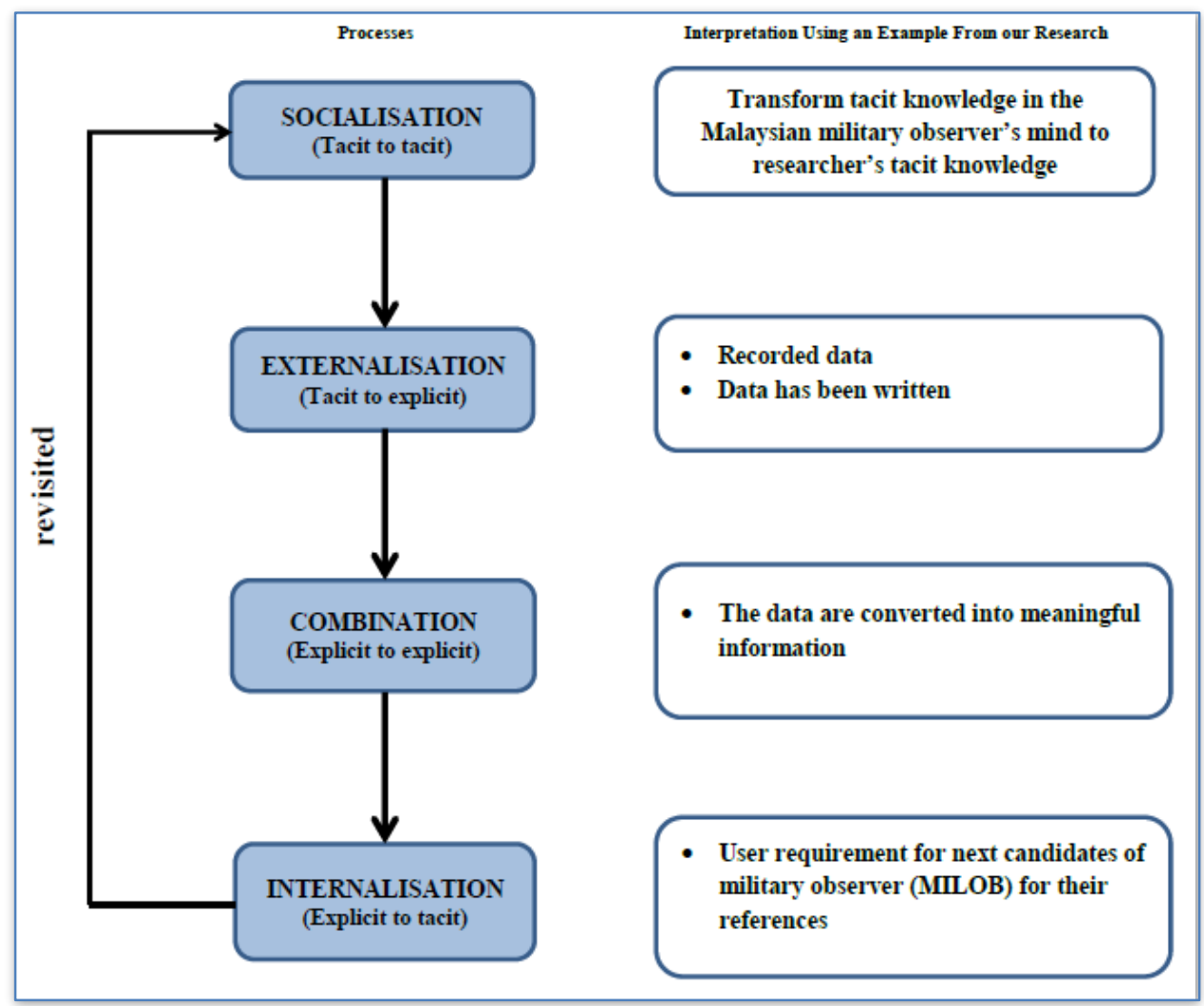

Figure 4: A knowledge based framework using Nonaka's model

The Application of Wisdom Hierarchy on Endsley's Model

The Endsley's model (Endsley, 1995) as a situational awareness model is shown in Figure 5. Meanwhile, Figure 6 illustrates the application of wisdom hierarchy on Endsley's model. Situational awareness model consists of three (3) levels: Level 1 is a perception of the elements in the environment. Level 2 is about comprehension of the current situation and final level is a projection of future status. The application of wisdom hierarchy was applied on level 3 that is comprehension.

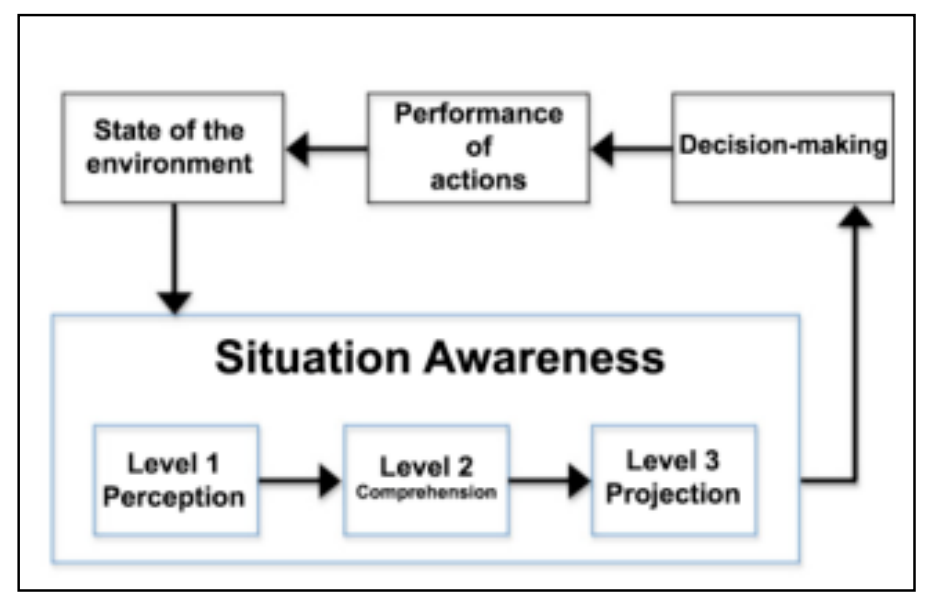

Figure 5: Endsley's Model adopted from (Endsley, 1995) 
INTERNATIONAL JOURNAL OF ACADEMIC RESEARCH IN BUSINESS AND SOCIAL SCIENCES Vol. 8, No. 6, June 2018, E-ISSN: 2222-6990 @ 2018 HRMARS

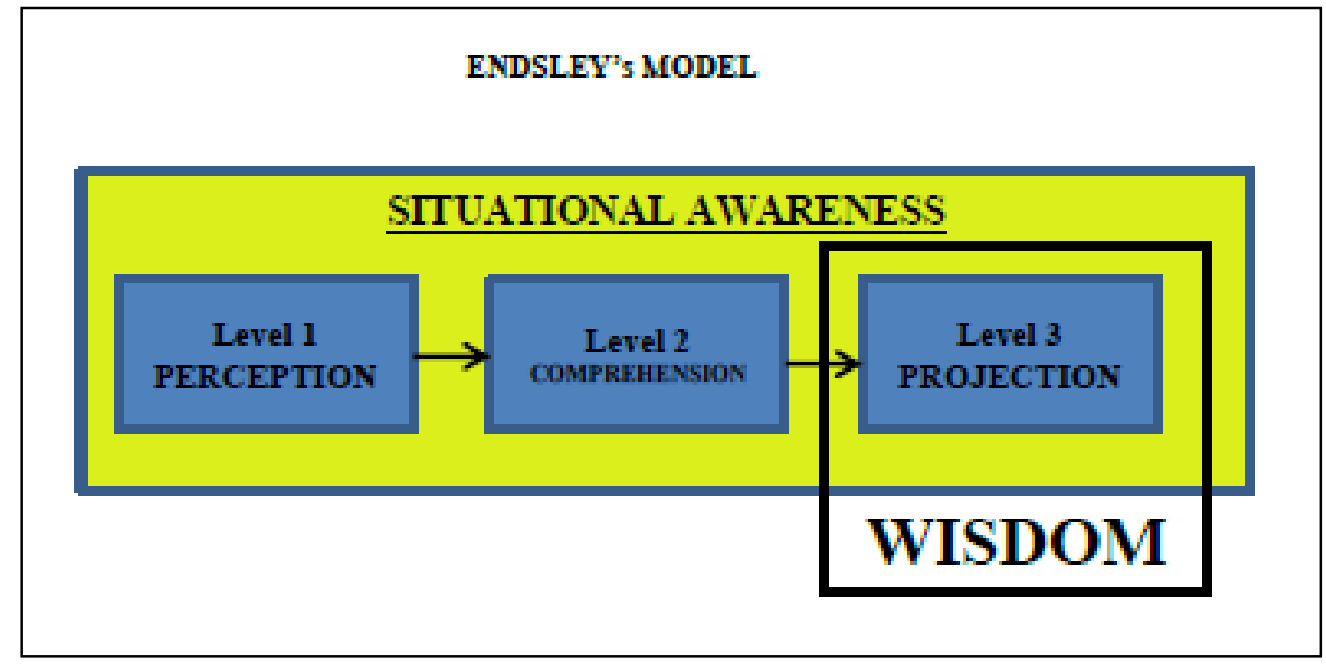

Figure 6: The application of wisdom hierarchy on Endsley's model adapted from Endsley's model (1995)

\section{Interpretation of Knowledge and Wisdom Hierarchy into Our Research}

The combination of these two (2) models was proposed by Wan Yusof et al. (2016) (see Figure 7) namely the model of Nonaka and Endsley model. Referring to the figures, Endsley model was combined within an externalisation and combination mode. There are three (3) levels of Endsley model which are perception level 1, level 2 comprehension and level 3 projection. Based on the interpretation of this study, level 1 is dealing with "observe the environment". While for level 2 is dealing with "understand each situation" and in level 3 is "list the possible action" (Wan Yusof et al., 2016).

During the process of conversion mode within externalisation and combination, researcher will collect the tacit knowledge with respect to situational awareness of a situation faced by the MILOB before entering the combination mode. For example, the situation is about the culture for local's people requesting for money. Based on the MILOBS' perception, everything that local's people helped, they will ask for money. For the comprehension level, MILOB understands that it is because local's people lack of money will lead them to ask for money on every help given. So, based on their wisdom on projection's level, the actions that MILOBS takes are provide small change that will be used for anything that will need their help. And if they do not want to give money, cigarettes will be given. 
INTERNATIONAL JOURNAL OF ACADEMIC RESEARCH IN BUSINESS AND SOCIAL SCIENCES Vol. 8, No. 6, June 2018, E-ISSN: 2222-6990 @ 2018 HRMARS

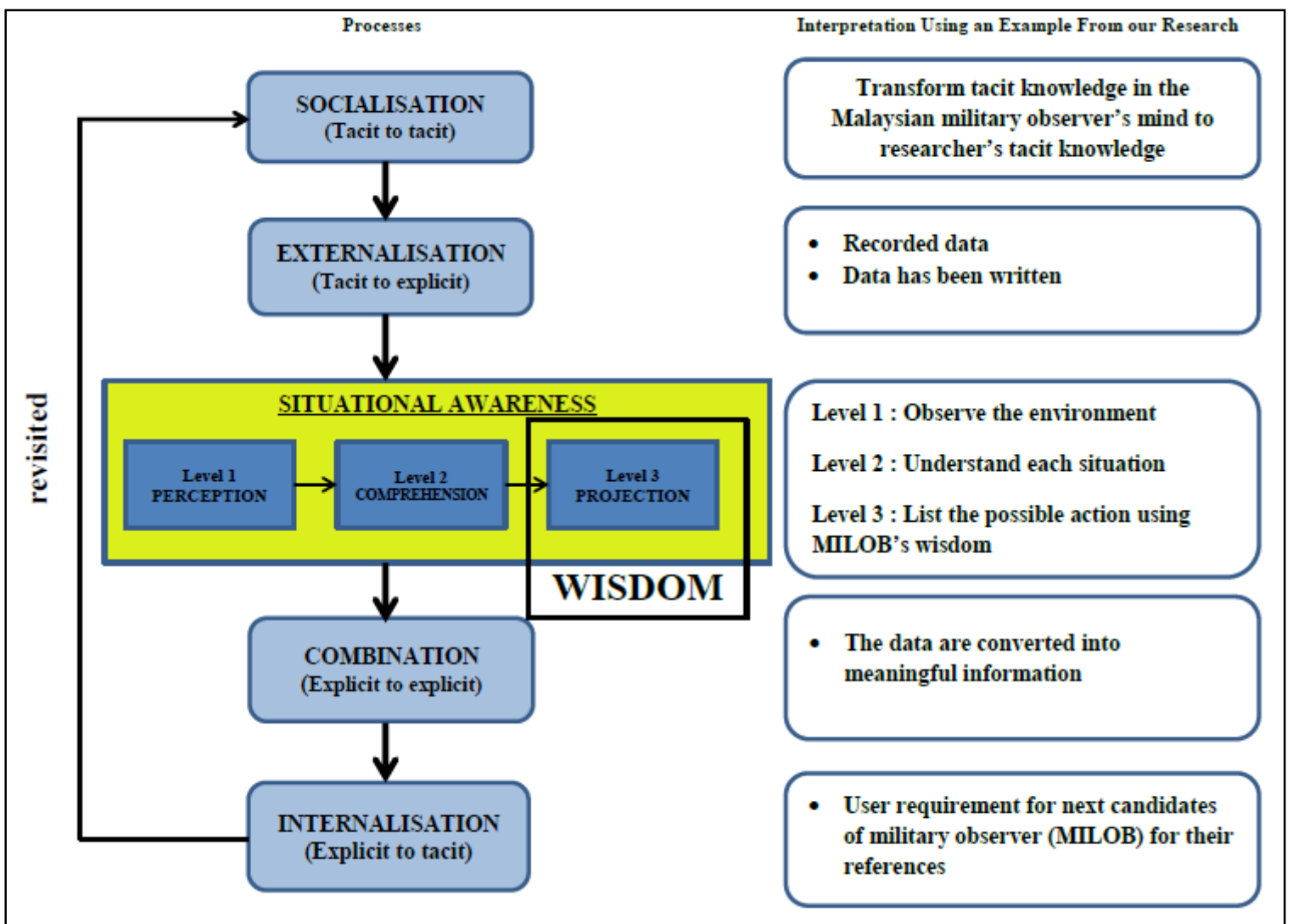

Figure 7: The application of wisdom into the combination on Nonaka's and Endsley's model adapted from Nonaka and Endsley's (1995)

For the combination level, the data is converted into meaningful information. For the last mode that is internalisation, the meaningful data will be a user requirement for the next candidates of MILOB for their additional references.

\section{Future Research}

This framework will be tested on Malaysian MILOBS to collect their tacit knowledge based on the situational awareness in the peacekeeping operations. The scope of this knowledge will focus on eight (8) core areas in peacekeeping operations such as, patrolling, negotiation, control of movement, observing and monitoring, escorting, search operations, show of force and cordon. The methodology approach for this research is a qualitative research with in-depth interview technique.

\section{Conclusion}

The wisdom in this study involves how a person is facing a situation and is able to list some actions that are appropriate and decide what is best for the situation. The combination of both models i.e. Nonaka and Endsley as a framework that will serve as a guideline for researchers to collect MILOB's experiences. The findings from this data collection will be made as a user requirement for other MILOBS in the future for their additional references in addition to the notes provided by the United Nations (UN). 
INTERNATIONAL JOURNAL OF ACADEMIC RESEARCH IN BUSINESS AND SOCIAL SCIENCES

Vol. 8, No. 6, June 2018, E-ISSN: 2222-6990 C 2018 HRMARS

\section{Acknowledgement}

The authors would like to thank the Ministry of Higher Education for providing us grant: NRGS/2013/UPNM/PK/P3 in order to undertake this research at the National Defence University of Malaysia.

\section{Corresponding Author}

Wan Su Emi Yusnita Wan Yusof ${ }^{1 *}$

Department of Computer Science, Faculty of Defense Science and Technology,

National Defense University of Malaysia,

Sungai Besi Camp,

57000 Kuala Lumpur, Malaysia

\section{References}

Anand, A., \& Singh, M. D. (2011). Understanding knowledge management. International Journal of Engineering Science and Technology, 3(2), 926-939. https://doi.org/http://www.ijest.info/docs/IJEST11-03-02-090.pdf

Cooper, P. (2014). Knowledge and Wisdom. Anaesthesia and Intensive Care Medicine, 15(1), 44-45. https://doi.org/10.1016/j.mpaic.2013.11.009

Endsley, M. R. (1995). Toward a Theory of Situation Awareness in Dynamic Systems. Human Factors: The Journal of the Human Factors and Ergonomics Society, 37(1), 32-64. https://doi.org/10.1518/001872095779049543

Fricke, M. (2008). The knowledge pyramid: a critique of the DIKW hierarchy. Journal of Information Science, 35(2), 131-142. https://doi.org/10.1177/0165551508094050

Frické, M. (2009). The knowledge pyramid: a critique of the DIKW hierarchy. Journal of Information Science, 35(2), 131-142. https://doi.org/10.1177/0165551508094050

Nonaka, I., Toyama, R., \& Konno, N. (2000). SECl, Ba and Leadership: A Unified Model of Dynamic Knowledge Creation. Long Range Planning, 33(1), 5-34. https://doi.org/10.1016/S00246301(99)00115-6

Rowley, J. (2007). The wisdom hierarchy: representations of the DIKW hierarchy. Journal of Information Science, 33(2), 163-180. https://doi.org/10.1177/0165551506070706

Rowley, J., \& Slack, F. (2009). Conceptions of wisdom. Journal of Information Science, 35(1), 110-119. https://doi.org/10.1177/0165551508092269

Gamble, P. R., \& Blackwell, J. (2001). Knowledge management: A state of the art guide: Kogan Page Publishers.

Nohuddin, P. N., Reizal, A., Ismail, L. K., \& Mohd Rizal, I. (2010). Knowledge management in military: A review for Malaysian Armed Forces' communities of practices.

Nohuddin, P. N., \& Zainol, Z. (2014). Context-based Keyword Pattern Cluster Analysis technique on tacit knowledge of military centre of expertise (COE): A preliminary study. Paper presented at the Computational Science and Technology (ICCST), 2014 International Conference on.

Nonaka, I. (1994). A dynamic theory of organizational knowledge creation. Organization science, 5(1), 14-37.

Nonaka, I. (2008). The knowledge-creating company: Harvard Business Review Press. 
INTERNATIONAL JOURNAL OF ACADEMIC RESEARCH IN BUSINESS AND SOCIAL SCIENCES

Vol. 8, No. 6, June 2018, E-ISSN: 2222-6990 @ 2018 HRMARS

Yusof, W. S. E. Y. W., Zakaria, O., \& Zainol, Z. (2016, 16-17 May 2016). Establishing of knowledge based framework for situational awareness using Nonaka's and Endsley's models. Paper presented at the 2016 International Conference on Information and Communication Technology (ICICTM).

Wan Yusof, W. S. E. Y., Zakaria, O., \& Zainol, Z. (2016). Establishing of Knowledge Based Framework for Situational Awareness Using Nonaka â€ $€^{\mathrm{TM}} \mathrm{s}$ And Endsley â€ $€^{\mathrm{TM}} \mathrm{s}$ Models, (May), 47-50.

Zakaria, O. (2013). Information Security Culture a human firewall approach. LAP Lambert Academic Pub. 2013, Germany.

Zainol, Z., Marzukhi, S., Nohuddin, P. N. E., Noormaanshah, W. M. U., \& Zakaria, O. (2017b). Document Clustering in Military Explicit Knowledge: A Study on Peacekeeping Documents. In H. Badioze Zaman, P. Robinson, A. F. Smeaton, T. K. Shih, S. Velastin, T. Terutoshi, A. Jaafar, \& N. Mohamad Ali (Eds.), Advances in Visual Informatics: 5th International Visual Informatics Conference, IVIC 2017, Bangi, Malaysia, November 28-30, 2017, Proceedings (pp. 175-184). Cham: Springer International Publishing.

Zainol, Z., Nohuddin, P. N. E., Mohd, T. A. T., \& Zakaria, O. (2017a). Text Analytics of Unstructured Textual Data: A Study on Military Peacekeeping Document using R Text Mining Package Paper presented at the the 6th International Conference on Computing \& Informatics. 